\title{
Effects of radon on soil microbial community and their growth
}

\author{
Kyu-Yeon Lee, Seon-Yeong Park, Chang-Gyun Kim ${ }^{\dagger}$ \\ Department of Environmental Engineering, INHA University, Incheon 22212, Republic of Korea
}

\begin{abstract}
The aim of this study was to estimate the microbial metabolic activity of indigenous soil microbes under the radon exposure with different intensity and times in the secured laboratory radon chamber. For this purpose, the soil microbes were collected from radon-contaminated site located in the G county, Korea. Thereafter, their metabolic activity was determined after the radon exposure of varying radon concentrations of $185,1,400$ and $14,000 \mathrm{~Bq} / \mathrm{m}^{3}$. The average depth variable concentrations of soil radon in the radon-contaminated site were 707 , 860 and $1,185 \mathrm{~Bq} / \mathrm{m}^{3}$ from 0,15 , and $30 \mathrm{~cm}$ in deep, respectively. Simultaneously, the soil microbial culture was mainly composed of Bacillus sp., Brevibacillus sp., Lysinibacillus sp., and Paenibacillus sp. From the radon exposure test, higher or lower radiation intensities compared to the threshold level attributed the metabolic activity of mixed microbial consortium to be reduced, whereas the moderate radiation intensity (i.e. threshold level) induced it to the pinnacle point. It was decided that radon radiation could instigate the microbial metabolic activity depending on the radon levels while they were exposed, which could consequently address that the certain extent of threshold concentration present in the ecosystem relevant to microbial diversity and population density to be more proliferated.
\end{abstract}

Keywords: Microbial viability, Radiation, Radon, Soil microorganism

\section{Introduction}

Radon $\left({ }^{222} \mathrm{Rn}\right)$, a radioactive inert gas with a half-life of $3.82 \mathrm{~d}$, is generated from alpha decay of radium $\left({ }^{226} \mathrm{Ra}\right)$, which is an intermediate of decay of uranium $\left({ }^{238} \mathrm{U}\right)$ and thorium $\left({ }^{232} \mathrm{Th}\right)$ in the soils and rocks [1,2]. Radon gas is released into the atmosphere from ground through its diffusion in the pore spaces in soils [3] and it significantly contributes to elevate indoor radon gas concentration through the some mechanisms including convection via cracks and openings, diffusion from soil via the pore space of building materials and emanation from building materials [4]. Thus, soil radon gas can be an effective predictor prone to determine indoor radon concentration. The strong positive correlation between soil radon potential and the percentage of homes above $200 \mathrm{~Bq} / \mathrm{m}^{3}$ was established from the survey in Canadian cites [5]. Moreover, the indoor radon concentration in dwellings is governed by ventilation habits, meteorological parameters, individual building characteristics [6], and by the geological and physical conditions of the soil (e.g., soil porosity, tortuosity, water content, particle size and permeability) [7].

In general, radon isotopes decay with emission of alpha particle into charged progenies such as polonium $\left({ }^{218} \mathrm{Po}\right.$ and $\left.{ }^{214} \mathrm{Po}\right)$, tending to easily form the molecular clusters, or attach to aerosols or dust particles in the air. Since after, they are inhaled and penetrated deep into the airways of lung and damages DNA of respiratory tissues [8], consequently leading to the respiratory functional changes and even the occurrence of lung cancer to people [9]. In Ireland, the number of patients diagnosed with lung cancer was 3.1 times higher in areas where $10-20 \%$ of households were above $200 \mathrm{~Bq} / \mathrm{m}^{3}$ of radon concentration, than in which $1 \%$ of households were [10].

In the soil environment, the indigenous microbes are inevitable from the ionizing radiations originated from the variety of natural radionuclides such as uranium $\left({ }^{238} \mathrm{U}\right)$ and americium $\left({ }^{241} \mathrm{Am}\right)$. The ionizing-radiation induce the detrimental effect on the nuclear materials cell DNA [11] through direct (ejection of electron from DNA) or indirect pathways (by reactive oxygen species produced from water radiolysis) [12, 13]. In particular, the gamma radiation has lower ionization ability and higher penetrability comparing to alpha and beta radiation and it can induce a mutagenic effect in microbes, even though the probability of gamma radiation was very low [14]. Bolsunobsky et al. demonstrated that gamma-radia-
This is an Open Access article distributed under the terms of the Creative Commons Attribution Non-Commercial License (http://creativecommons.org/licenses/by-nc/3.0/) which permits unrestricted non-commercial use, distribution, and reproduction in any medium, provided the original work is properly cited.

Copyright (C) 2020 Korean Society of Environmental Engineers
Received September 13 Accepted January 22, 2019

${ }^{\dagger}$ Corresponding author

Email: cgk@inha.ac.kr

Tel: +82-32-860-7561 Fax: +82-32-876-2351

ORCID: 0000-0002-8668-3281 
tion induced the genetic mutation and simultaneously impaired their growth and survival rate of microbial strains, Salmonella typhimurium and Escherichia coli [13]. Min et al. showed that DNA damage in bacterial cells was positively correlated with the dose of gamma radiation [15]. On the contrast, a few scientific researches proposed that the low-dose of radiation gave the stimulatory effect, increasing function and resistance of the cellular organism [16, 17]. However, to date, this phenomenon has been controversy [18].

Herein, this study aimed to estimate the microbial metabolic activity under the exposure of the varying radon concentrations (i.e., $185,1,400$ and $14,000 \mathrm{~Bq} / \mathrm{m}^{3}$ ) in the laboratory radon chamber equipped with the radon reservoir. Prior to this, the indigenous soil microbes were collected from the different depth intervals, i.e., 0,15 , and $30 \mathrm{~cm}$ from radon-contaminated site along with immediately surrounded sites located in the G county, Korea, and then we compared the physicochemical properties of soil and microbial density in focusing on the radon-contaminated soils. Concurrently, their metabolic activity was determined after the radon exposure.

\section{Materials and Methods}

\subsection{Characterization of Physicochemical Properties of Radon-Contaminated Soil}

Soil samples were collected in the four sampling sites including radon-contaminated site $(\mathrm{R})$ and three periphery sites (as of controls, C1, C2, and C3) where they are separated by equal distance of $2 \mathrm{~m}$, located in $\mathrm{G}$ county, Korea (Fig. 1 and Table 1). At the different depth intervals of 0,15 and $30 \mathrm{~cm}$ below soil surface
Table 1. List of Samples Named after Sampling Site and Depth at which the Sample was Taken

\begin{tabular}{cccc}
\hline Location & $\begin{array}{c}\text { Sample } \\
\text { name }\end{array}$ & Location & $\begin{array}{c}\text { Sample } \\
\text { name }\end{array}$ \\
\hline $\begin{array}{c}\text { Radon contaminated point } \\
\text { Top soil }\end{array}$ & R-T & $\begin{array}{c}\text { Control } 2 \\
\text { Top soil }\end{array}$ & C2-T \\
\hline $\begin{array}{c}\text { Radon contaminated point } \\
\text { Depth } 15 \mathrm{~cm}\end{array}$ & R-1 & $\begin{array}{c}\text { Copth } 15 \mathrm{~cm} \\
\text { Depth }\end{array}$ & C2-1 \\
\hline $\begin{array}{c}\text { Radon contaminated point } \\
\text { Depth 30 cm }\end{array}$ & R-3 & $\begin{array}{c}\text { Control } 2 \\
\text { Depth 30 cm }\end{array}$ & C2-3 \\
\hline $\begin{array}{c}\text { Control } 1 \\
\text { Top soil }\end{array}$ & C1-T & $\begin{array}{c}\text { Control } 3 \\
\text { Top soil }\end{array}$ & C3-T \\
\hline $\begin{array}{c}\text { Control } 1 \\
\text { Depth 15 cm }\end{array}$ & C1-1 & $\begin{array}{c}\text { Control } 3 \\
\text { Depth 15 cm }\end{array}$ & C3-1 \\
\hline $\begin{array}{c}\text { Control } 1 \\
\text { Depth 30 cm }\end{array}$ & C1-3 & $\begin{array}{c}\text { Control 3 } \\
\text { Depth 30 cm }\end{array}$ & C3-3 \\
\hline
\end{tabular}

in each sampling site, samples were taken using a shovel sterilized with $70 \%(\mathrm{v} / \mathrm{v})$ ethanol solution and then put into a $1 \mathrm{~L}$ of amber jar without headspace. Samples were stored on ice and transferred immediately to a laboratory. The radon concentration was measured by Fast Radon Monitor (FRD 400, Radon FT Lab, Korea) in the tightly-sealed container ( $34 \times 24.5 \times 17.5 \mathrm{~cm}$, Easy Phillim). Additionally, $\mathrm{pH}$ and electrical conductivity of soil samples were monitored by portable meters (Orion star A214 and Orion star A222, Thermo Scientific, Korea) and moisture content, organic matter, and grain-size were also analyzed according to each analytical protocol.
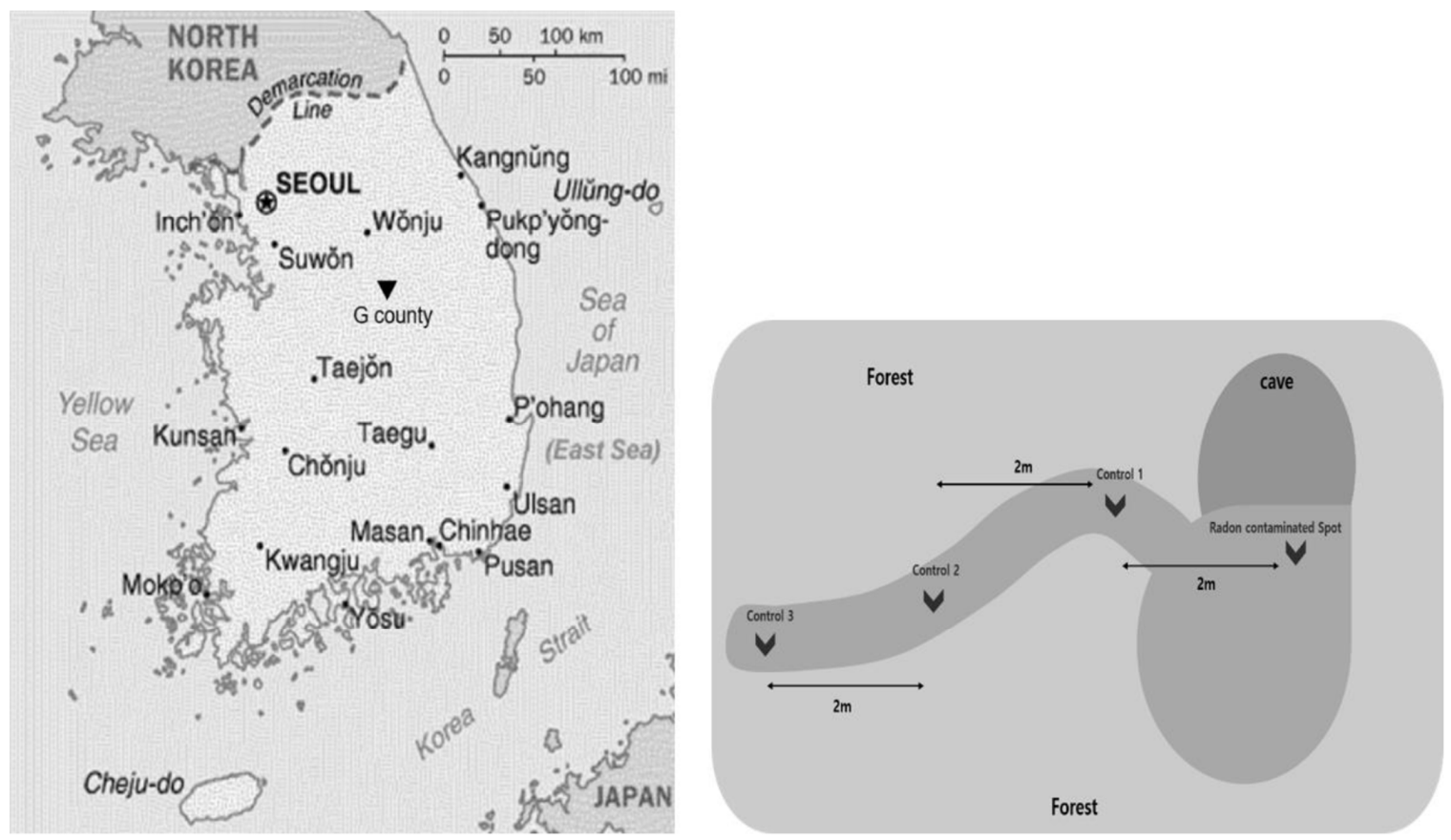

Fig. 1. Schematic of locations of 4 sampling sites in G county, Korea. 


\subsection{Estimation of Microbial Activity of Soil Microbes}

The microbial activity of soil microbes was estimated by two biological quantification methods, direct colony enumeration and dehydrogenase activity assay. First, for the direct colony enumeration, five grams of soil sample were suspended in $50 \mathrm{~mL}$ of sterilized double distilled water and mixed for $10 \mathrm{~min}$ at $200 \mathrm{rpm}$ using a separator funnel shaker (MMV-1000W, EYELA, Japan) followed by standing for $30 \mathrm{~min}$. The supernatants were serially 10 -fold diluted, and then $20 \mu \mathrm{L}$ of them were inoculated onto the LB agar plate (composed of Tryptone $10 \mathrm{~g} / \mathrm{L}$; Yeast extract $5 \mathrm{~g} / \mathrm{L}$; $\mathrm{NaCl} 10$ $\mathrm{g} / \mathrm{L}$; and Agarose $15 \mathrm{~g} / \mathrm{L})$. After cultivating them at $30^{\circ} \mathrm{C}$ for $24 \mathrm{~h}$ in the static incubator (VS-1203P 1N, Vision Science Co., Ltd., Korea), bacterial colonies were enumerated as of colony forming unit (CFU). Simultaneously, for the estimating the dehydrogenase activity, $1 \mathrm{~mL}$ of supernatant was gently-mixed with $10 \mathrm{~mL}$ of LB broth into a sterile conical centrifuge tube (Falcon ${ }^{\mathrm{TM}}$, USA), and then incubated for $24 \mathrm{~h}$ at $30^{\circ} \mathrm{C}$. After that, $500 \mu \mathrm{L}$ of the bacterial culture was put in a $2 \mathrm{~mL}$ tube and centrifuged at $10,000 \times \mathrm{g}$ for $10 \mathrm{~min}$ (Centrifuge 5415D, Eppendorf, Korea) to remove remaining nutrient medium, and the cell pellet was suspended with sterile double distilled water. Followed by, it was mixed with $20 \mu \mathrm{L}$ of $2 \%$ (w/v) 2,3,5-triphenyltetrazolium chloride solution sterilized by mixed cellulose acetate syringe filter $(0.45 \mu \mathrm{m}, 25 \mathrm{AS} 045 \mathrm{AS}$, Advantec, Japan) and $100 \mu \mathrm{L}$ of $1 \%(\mathrm{w} / \mathrm{v})$ glucose (Sigma-Aldrich, USA), and subsequently incubated at $30^{\circ} \mathrm{C}$ for $6 \mathrm{~h}$ (VS-1203P $1 \mathrm{~N}$, Vision science, Korea). Finally, $1 \mathrm{~mL}$ of chilled methanol was added to extract tetrazolium formazan produced by microbial reduction of 2,3,5-triphenyltetrazolium chloride, after which the absorbance of the extract was determined at $490 \mathrm{~nm}$ through the UV-Vis Spectrometer (UV-3300, Humas, Korea).

\subsection{Identification of Microbial Strains Based on 16S rDNA Analysis}

Microbial colonies cultivating on LB agar plates in the procedure of direct colony enumeration were separately transferred into LB broth and incubated for $24 \mathrm{~h}$ at $30^{\circ} \mathrm{C}$ (VS-1203P 1N, Vision Science Co., Ltd., Korea). The total genomic DNA was extracted by using Fast DNA ${ }^{\mathrm{TM}}$ SPIN Kit for Soil (MP Biomedical, USA). Polymerase chain reaction was performed using the universal primer set of 27F (5'-AGA GTT TGA TCM TGG CTC AG-3') and 1492R (5'-TAC GGY TAC CTT GTT ACT T-3'). Amplified PCR products were obtained through the gel electrophoresis (Mupid- $\alpha$, TAKARA, Japan) using 1\% (w/v) agarose in 0.5X TAE buffer (2.424 g Tris base, $0.571 \mathrm{~mL}$ acetic acid and $5 \mathrm{mM}$ EDTA in $1 \mathrm{~L}$ distilled water), and then they were purified by Dyne Bio Power Gel Extraction Kit (Dyne Bio Inc., Korea). 16S rDNA gene sequence analysis was conducted using an ABI 3730XL DNA Analyzer (Thermo Fisher Scientific, USA). Nucleotide sequences of alignments were performed using Gene bank database on NCBI (National Center for Biotechnology Information: http://www.NCBI.nlm.nih.gov). Microorganism species were acceptably identified based on 95\% sequence homology matched to the database.

\subsection{Estimation of Microbial Metabolic Activity after Radon Exposure}

Soil microbes enriched in LB broth were put into the laboratory radon chamber $(1 \times 1 \times 1 \mathrm{~m}$, acrylic materials) equipped with radon reservoir (RN-1025, Pylon, Canada) and radon measuring instrument (FRD 1600, Radon FT Lab, Korea) and they were exposed to radon radiation with varying radon concentrations (i.e., 185, 1,400, and $14,000 \mathrm{~Bq} / \mathrm{m}^{3}$ ) and exposure time (i.e., 1, 3, and 5 h). Since then, $5 \mathrm{~mL}$ of the microbial suspensions were inoculated into the $150 \mathrm{~mL}$ of synthetic nutrient solution containing glucose 0.5 g/L; $\mathrm{NH}_{4} \mathrm{Cl} 0.0382 \mathrm{~g} / \mathrm{L} ; \mathrm{ZnSO}_{4} .7 \mathrm{H}_{2} \mathrm{O} 0.574 \mathrm{~g} / \mathrm{L} ; \mathrm{MnSO}_{4} .7 \mathrm{H}_{2} \mathrm{O}$ $0.446 \mathrm{~g} / \mathrm{L} ; \mathrm{NaMoO}_{4} .2 \mathrm{H}_{2} \mathrm{O} 0.096 \mathrm{~g} / \mathrm{L} ; \mathrm{CoCl}_{2} .6 \mathrm{H}_{2} \mathrm{O} 0.096 \mathrm{~g} / \mathrm{L}$; $\mathrm{FeCl}_{3} .6 \mathrm{H}_{2} \mathrm{O} 5.0 \mathrm{~g} / \mathrm{L} ; \mathrm{AlCl}_{3} .6 \mathrm{H}_{2} \mathrm{O} 0.672 \mathrm{~g} / \mathrm{L}$; and $\mathrm{KI} 0.166 \mathrm{~g} / \mathrm{L}$. They were subsequently incubated in a shaking incubator at $30^{\circ} \mathrm{C}$ with the agitation of $160 \mathrm{rpm}$. Culture growth was monitored with optical density at $600 \mathrm{~nm}$ using the UV/Vis spectrometer (UV-3300, Humas, Korea) with direct colony enumeration, and its metabolic activity including enzymatic activity and organic uptake rate were determined by dehydrogenase activity assay (previously described in section 2.2) and chemical oxygen demand (COD) measurement, respectively.

\section{Results and Discussion}

\subsection{Radon Concentration and Physicochemical Properties of Soil Samples}

Soil radon concentration tended to decrease with the further distance from the natural radon source (Fig. 2); average radon concentrations on each sampling point were $917 \mathrm{~Bq} / \mathrm{m}^{3}(\mathrm{R}), 192 \mathrm{~Bq} / \mathrm{m}^{3}$ (C1), $135 \mathrm{~Bq} / \mathrm{m}^{3}$ (C2), and $78 \mathrm{~Bq} / \mathrm{m}^{3}$ (C3), respectively. Meanwhile, 707, 860, and 1,185 $\mathrm{Bq} / \mathrm{m}^{3}$ was measured at different soil depths of 0,15 , and $30 \mathrm{~cm}$ in the radon contaminated soil (R), indicating that the deeper soil has a higher radon radiation intensity than shallower one. The periphery soils (C1, C2, and C3) had a same tendency for deeper soils. The levels of radon concentration were increased at deeper depths because there were more radon sources neighbored in it so that its movement gassing out to atmosphere should be passively limited compared to that of shallower soil depths. It was well known that the atmospheric radon concentration observed near the ground surface was mainly composed of gaseous radon originated from topmost layer of soil and rock surface [7]. Furthermore, referring to Kaur et al. [19], the presence of underlying bed-rocks and the type of soil permeability might ascribe to a

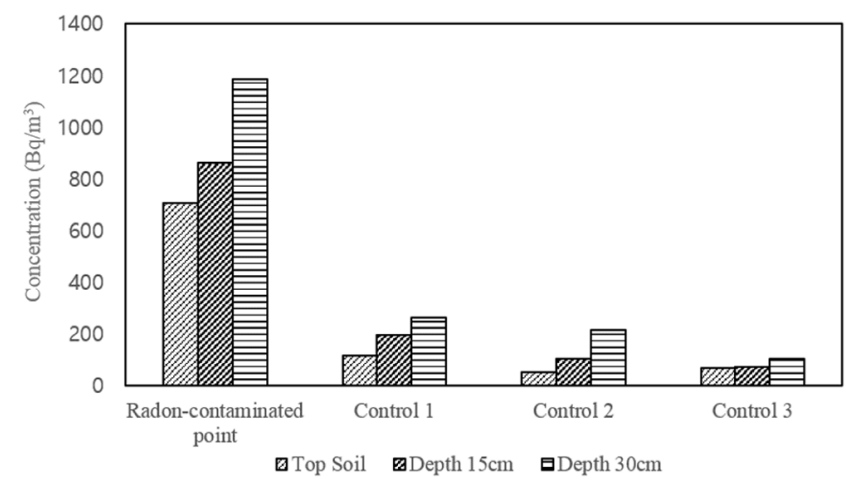

Fig. 2. Radon concentration measured in radon-contaminated and periphery soils of different soil depths. 
difference in radon concentration depending upon sampling sites and soil depths.

Meanwhile, soil radon concentration also depends on the soil physicochemical properties including soil structure, porosity, grain-size, permeability, radium contents, emanation coefficient, and moisture content [20]. In this study, $\mathrm{pH}$, electric conductivity, moisture content, grain-size and organic matter were investigated to compare soil properties between radon-contaminated and periphery sites. First, the $\mathrm{pH}$ and electrical conductivity were $\mathrm{pH}$ $5.71 \pm 0.17$ and $0.59 \pm 0.06 \mathrm{ds} / \mathrm{m}$ in the radon-contaminated soil, respectively and they were comparable with soil samples collected from the C1, C2 and C3 sites, although experimental values in periphery soils were slightly lower. Second, organic matter concentration was also observed no significant difference regardless of either sampling point or soil depths. On the other hand, moisture content tended to decrease with a distance from the natural radon source, similar to radon concentration. It was reported that the moisture content induced the increasing the radon exhalation rates [21], however when the soil pores were saturated by water, the exhalation rate was decreased due to adsorption of radon onto the solid mineral phase or liquid phase [22]. In this study, the moisture content with very broad range from $20 \%$ to $60 \%$ was relatively higher than other previous studies because the sampling was conducted after rainy spell. Thus, the relationship between the moisture content and radon concentration was difficult to be clearly established. However, the particle size distribution analysis showed that the proportion of sand ranging from $0.02 \mathrm{~mm}$ to $2 \mathrm{~mm}$ was much higher observed in the radon sources whereas it was declined as far as from them. The sandy soils with more bigger grain size increased soil permeability and consequently contributed to increasing the radon diffusion coefficient [9]. In the meantime, iron species were measured to be higher concentration than those of other metals regardless of sampling sites as can be seen generally on the earth surface.

\subsection{Soil Microorganisms at the Radon Source}

Fig. 3 and 4 showed the microbial population density (as of colony forming in the LB agar plate) and dehydrogenase activity of indigenous soil microorganisms, respectively, observed from both the radon-contaminated and its immediately surrounded soil. In this experiment, as much as the radiation intensity was higher and soil depth was deeper at the study area, the increased number of colonies formed was observed. From this, average of microbial population densities were $5.47 \times 10^{8}, 4.12 \times 10^{8}, 1.57 \times 10^{8}$ and $0.76 \times 10^{8} \mathrm{CFU} / \mathrm{mL}$ for the sampling sites (R, C1, C2 and C3), together with $2.56 \times 10^{8}, 2.72 \times 10^{8}$, and $3.66 \times 10^{8} \mathrm{CFU} / \mathrm{mL}$ for the soil depths $(0,15$ and $30 \mathrm{~cm})$, respectively. Likewise, dehydrogenase activity was decreased as increasing the distance from the radon natural source, while it was increased as soil depths were increased. This implied that the radon source may have a threshold level that can moreover contribute to proliferating a microbial growth and to exporting diversity at the given site.

Based on 16S rDNA analysis, the indigenous soil microbes were commonly identified by genera of Bacillus, Brevibacillus,

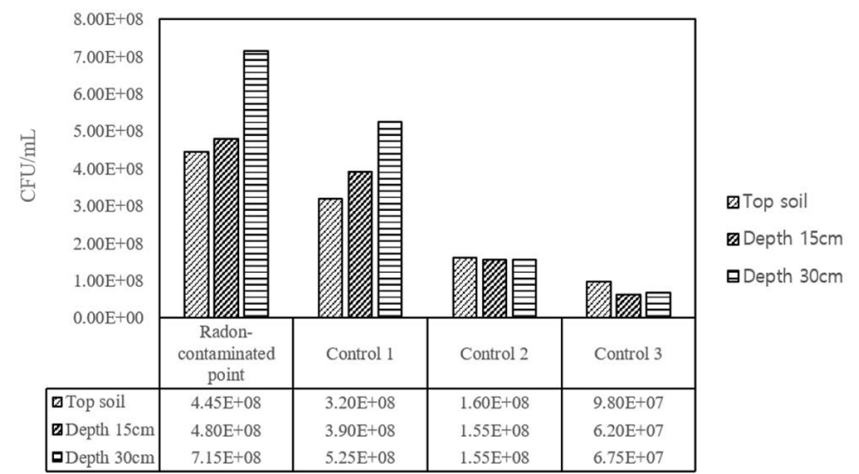

Fig. 3. Microbial population density determined from the dilution plate method for three different depths per sampling sites.

Lysinibacillus, and Paenibacillus, regardless of sampling site and soil depths. Each genus included Bacillus cereus, Bacillus subtilis, Bacillus pseudomycoides, Bacillus simplex, Brevibacillus brevis, Lysinibacillus macroides, Paenibacillus pabuli, and Paenibacillus peroriae. Bacillus sp. and Lysinibacillus sp. can grow in the uranium-enriched medium [23], and in particular, Bacillus subtilis adsorbs the uranyl compounds onto their surfaces [24, 25]. Additionally, these microbial strains were known as the potential remediator on the uranium-contaminated soil by sequestrating the uranium [26] or other radionuclides.

\subsection{Effect of Microbial Metabolic Activity to Radon Exposure}

The variations of microbial diversity and metabolic activity under the radon exposure were investigated on the radon radiation intensities of $185,1,400$, and $14,000 \mathrm{~Bq} / \mathrm{m}^{3}$ for 1,3 , and $5 \mathrm{~h}$, respectively. First, the result of microbial diversity of indigenous soil microorganisms based on $16 \mathrm{~S}$ rDNA analysis indicated that dominant species in the microbial culture exposed with 1,400 $\mathrm{Bq} / \mathrm{m}^{3}$ of radon radiation were Bacillus sp. including Bacillus cereus and Bacillus subtilis, regardless of their original habitat environment. Interestingly, Microbacterium sp. and Arthrobacter sp. were more abundantly observed comparing to the not-exposed to radon. These microbial strains, Microbacterium sp. [27] and Arthrobacter sp. [28] has a high resistance to uranium along with the sequestration ability of uranium. These bacterial strains were also observed more predominantly than those of other strains,

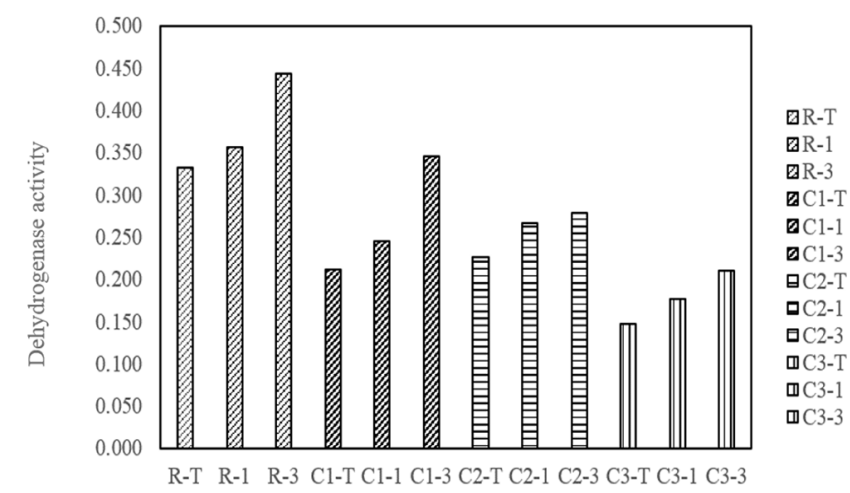

Fig. 4. Comparison of dehydrogenase activity in soil samples. 
in the $14,000 \mathrm{~Bq} / \mathrm{m}^{3}$ of radon radiation. Mumataz et al. found that the microbes could grow in the medium containing high concentration of uranium in the Ranger Uranium Mine [23].

Secondly, the variation of metabolic activity after radon exposure was estimated by monitoring microbial population density (i.e., optical density at $600 \mathrm{~nm}$ and colony enumeration), dehydrogenase activity and glucose uptake. Microbial growth of exposed to varying radiation intensities were increased with the incubation time (Fig. S1, S2 and S3) and the maximum microbial density was achieved after 8 to $12 \mathrm{~h}$ of incubation. The highest microbial density was found in the experimental sets obtained after $1,400 \mathrm{~Bq} / \mathrm{m}^{3}$ of radon radiation employing microbial strains isolated from the radon contaminated soil with its depth of $30 \mathrm{~cm}$ (R-3) (Fig. S2(b)). Meanwhile,
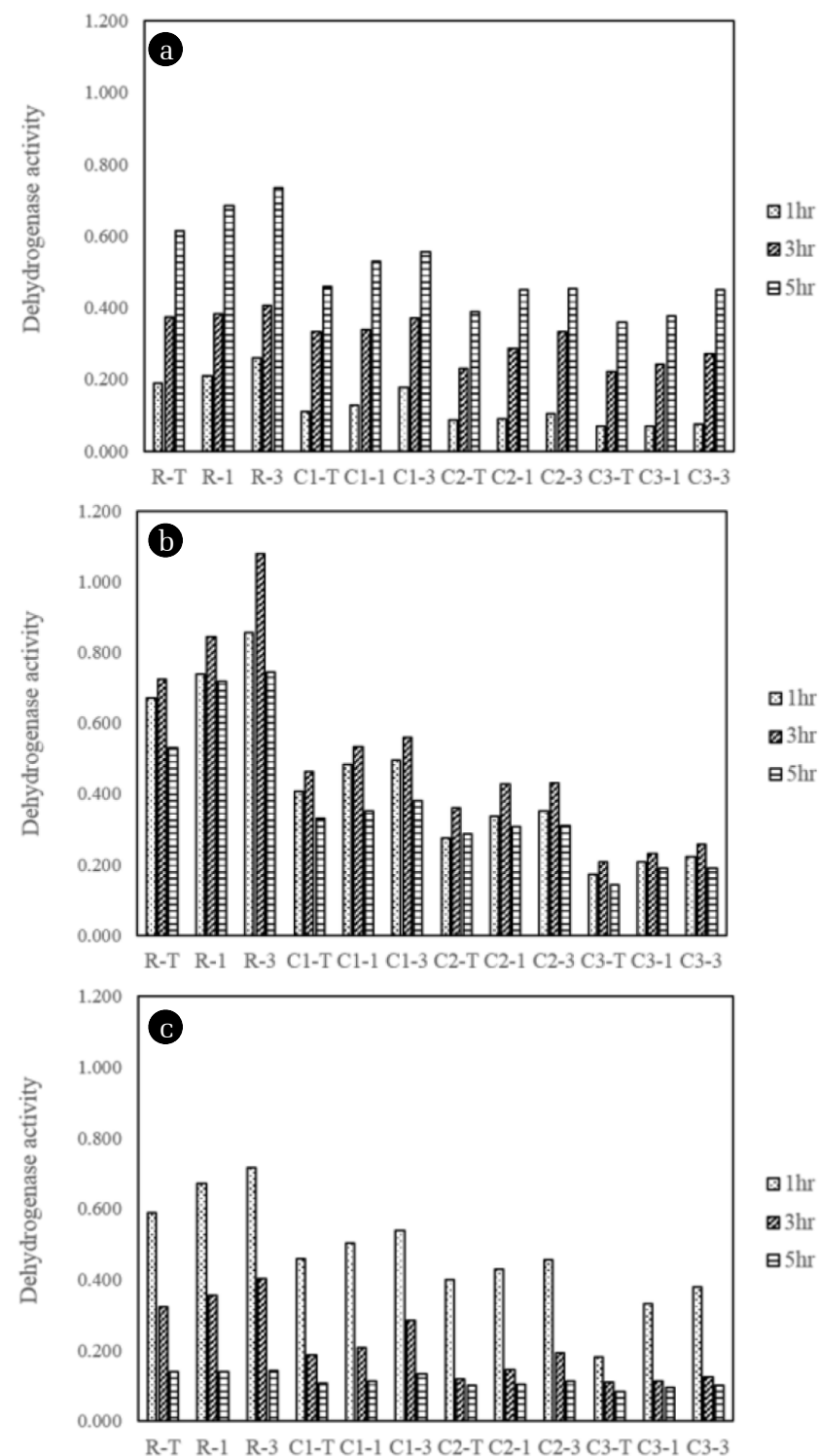

Fig. 5. Microbial dehydrogenase activity following radon exposure with different exposure times (1, 3, and $5 \mathrm{~h}$ ) according to radiation intensity of (a) $185 \mathrm{~Bq} / \mathrm{m}^{3}$, (b) $1,400 \mathrm{~Bq} / \mathrm{m}^{3}$, and (c) 14,000 $\mathrm{Bq} / \mathrm{m}^{3}$. either lower $\left(185 \mathrm{~Bq} / \mathrm{m}^{3}\right)$ or higher radon concentration $(14,000$ $\mathrm{Bq} / \mathrm{m}^{3}$ ) resulted in the relatively lower microbial density comparing to the radon exposure of $1,400 \mathrm{~Bq} / \mathrm{m}^{3}$.

In this context, the result of the dehydrogenase activity (Fig. 5) and direct colony enumeration (Fig. S4, S5, and S6) also showed that the highest number of viable microorganism was detected when the microbial culture was exposed to $1,400 \mathrm{~Bq} / \mathrm{m}^{3}$ for 3 h. Simultaneously, Fig. 5 was clearly demonstrated that microorganism isolated from the radon-contaminated soil had a greater metabolic activity than other sampling site where the soil radon concentrations were less than $200 \mathrm{~Bq} / \mathrm{m}^{3}$. Meanwhile, the exposure time could be an important factor to determining the microbial activity. At the $185 \mathrm{~Bq} / \mathrm{m}^{3}$ of radon concentration, dehydrogenase activity and number of colonies were gradually increased as incubation time was extended from 1 to $5 \mathrm{~h}$. At the $1,400 \mathrm{~Bq} / \mathrm{m}^{3}$, the maximum microbial viability was determined in $3 \mathrm{~h}$ of radon exposure, and then it was slightly decreased in $5 \mathrm{~h}$. Final radon concentration, $14,000 \mathrm{~Bq} / \mathrm{m}^{3}$ had a lower dehydrogenase activity and microbial population density than other experimental condition and steeply decrease of them against increasing exposure time. Hence, it might be implied that the higher radon concentration combined with exposure time above their threshold induced from environmental habitats could exacerbate the microbial activity.

Furthermore, the result of organic uptake rate (Fig. 6) was corresponded with microbial density and dehydrogenase activity. For all microbial culture of experiments, the organic uptake was completed in the $12 \mathrm{~h}$ of incubation time, which has no longer significant increase in microbial density, and the maximum organic uptake at this time was slightly different from the radon exposure condition. In particular, the highest organic uptake was observed in the microbial culture isolated from the radon contaminated soil with depth of $30 \mathrm{~cm}$ (R-3) after $1 \mathrm{~h}$ of radon exposure for each radon radiation intensity. COD value was decreased to 384 $\mathrm{mg} \mathrm{O}_{2} / \mathrm{L}$ (for $185 \mathrm{~Bq} / \mathrm{m}^{3}$ of exposure), $288 \mathrm{mg} \mathrm{O} / 2 / \mathrm{L}\left(1,400 \mathrm{~Bq} / \mathrm{m}^{3}\right.$ ) and $640 \mathrm{mg} \mathrm{O}_{2} / \mathrm{L}\left(14,000 \mathrm{~Bq} / \mathrm{m}^{3}\right)$ from initial concentration of 1,700 mg $\mathrm{O}_{2} / \mathrm{L}$, respectively.

Regarding on the whole experimental results of radon exposure, the medium level of radiation (i.e., $1,400 \mathrm{~Bq} / \mathrm{m}^{3}$ ) similar to the microbial habitat of study area could stimulate the microbial growth as well as increase substrate utilization capacity [17, 29]. Whereas, the higher or lower radiation compared to it attributed to the relatively lower metabolic activity of microbes. As aforementioned, high-dose ionizing radiation of radionuclides induce to damage DNA, which consequently bring to the cell mutation or the inhibition of both cell growth and metabolic reaction. It was clearly observed that dehydrogenase activity and organic utilization were more decreased after radon-radiation of $14,000 \mathrm{~Bq} / \mathrm{m}^{3}$. While, the low-dose and short time of radiation might be negligible in the viewpoint of the adverse impact of microbial metabolic reaction. It should be present a threshold level for the radiation intensity influencing on microbial resistance. Beyond it, its activity has been seriously impaired, whereas lower than that, it has not been influenced [29]. Furthermore, a few microbial strains are strongly resistant to the radiation of radionuclides. For example, Deinococcus spp. compensates for extensive DNA damage through adaptions such as the genetic redundancy and the enzymatic re- 

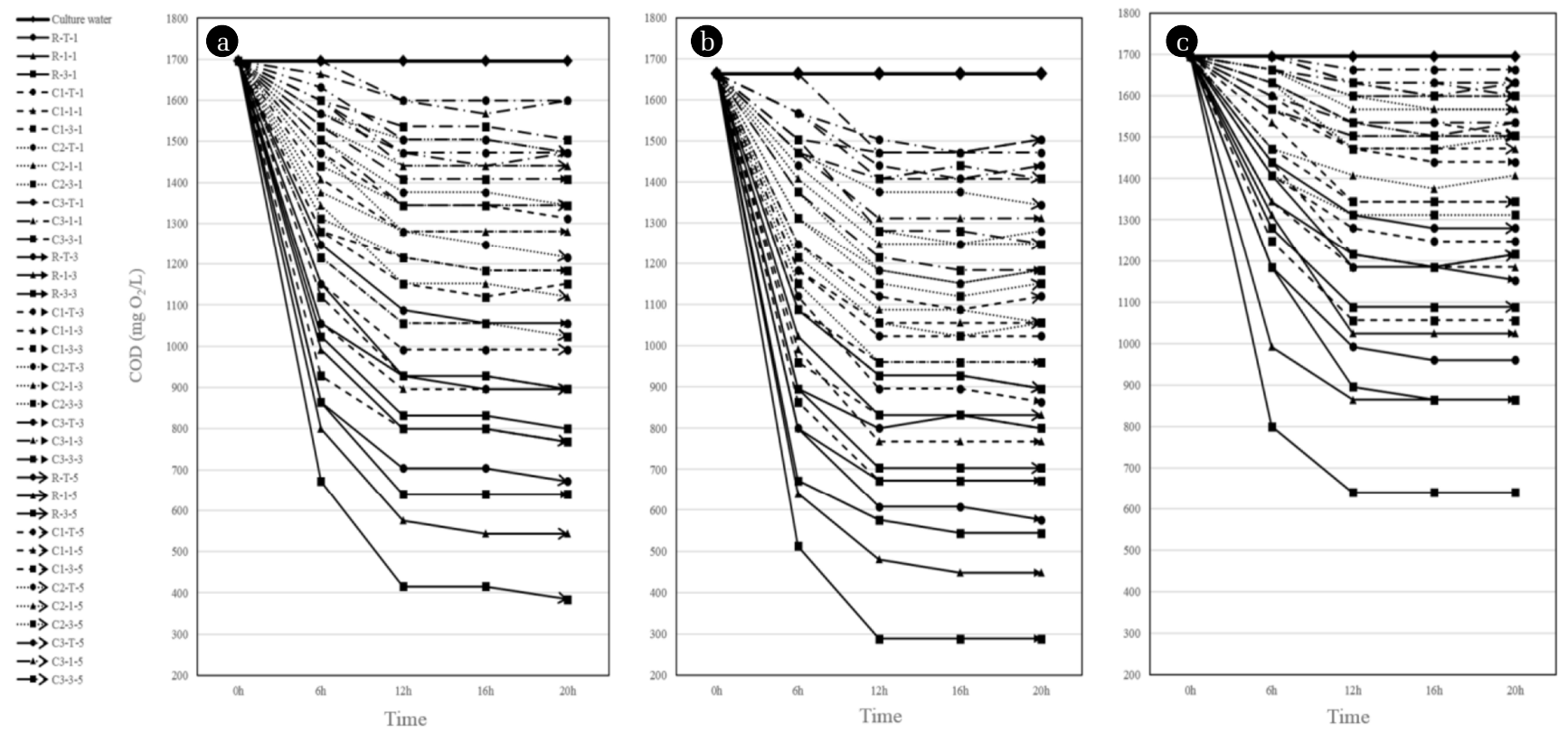

Fig. 6. Organic uptake rate of microbial strains exposed to a radiation intensity of (a) $185 \mathrm{~Bq} / \mathrm{m}^{3}$, (b) 1,400 Bq/ $\mathrm{m}^{3}$, and (c) $14,000 \mathrm{~Bq} / \mathrm{m}^{3}$ for different exposure times, respectively.

action of specialized proteins that have an ability to protect and repair an impaired DNA following radiation [30, 31]. Some bacterial strains can be viable and metabolically active in the extreme habitation condition akin to the disposal site of radioactive waste, which capable of uranium sequestration [26, 28]. Therefore, it can be inferred that the radiation intensity of radon observed from the study area and tested from the laboratory could give a threshold level for microbes to persistently sustain and moreover proliferlate their viability and population density in a certain range of radiation (i.e., $1,400 \mathrm{~Bq} / \mathrm{m}^{3}$ ).

\section{Conclusions}

It was the first study to investigate the microbial activity of indigenous soil microorganism against radon exposure. Soil microorganisms were mainly composed of Bacillus sp., Brevibacillus sp., Lysinibacillus sp. and Paenibacillus sp., and their microbial density and dehydrogenase activity were higher as the closer to the natural radon source. Laboratory radon exposure test with different radon radiation intensities and exposure time showed that microbial activity including microbial population density, dehydrogenase activity and organic uptake was higher in the experimental sets employing the microbial culture isolated from the radon-contaminated soil, same as the result of field study. And the higher level of radon and longer exposure time could diminish the microbial metabolic activity. Consequently, radon radiation could instigate the microbial metabolic activity depending on the radon levels while they were exposed, which could address that the certain extent of threshold concentration present in the ecosystem relevant to microbial diversity and population density.

\section{Acknowledgments}

This research has been conducted by the financial support of Inha University research grant.

\section{References}

1. Saad AF, Abdallah RM, Hussein NA. Physical and geometrical parameters controlling measurements of radon emanation and exhalation from soil. Appl. Radiat. Isot. 2018;137:273-279.

2. Li Y, Tan W, Tan K, et al. The effect of laterite density on radon diffusion behavior. Appl. Radiat. Isot. 2018;132:164-169.

3. Chitra N, Danalakshmi B, Supriya D, et al. Study of radon and thoron exhalation from soil samples of different grain sizes. Appl. Radiat. Isot. 2018;133:75-80.

4. Kovler K, Perevalov A, Steiner V, Rabkin E. Determination of the radon diffusion length in building materials using electrets and activated carbon. Health Phys. 2004;86:505-516.

5. Chen J, Ford KL. A study on the correlation between soil radon potential and average indoor radon potential in Canadian cities. J. Environ. Radioact. 2017;166:152-156.

6. Schubert M, Musolff A, Weiss H. Influences of meteorological parameters on indoor radon concentrations (222Rn) excluding the effects of forced ventilation and radon exhalation from soil and building materials. J. Environ. Radioact. 2018;192:81-85.

7. Prasad G, Ishikawa T, Hosoda M, et al. Estimation of radon diffusion coefficients in soil using an updated experimental system. Rev. Sci. Instrum. 2012;83:093503.

8. Denton GRW, Namazi S. Indoor radon levels and lung cancer incidence on Guam. Procedia Environ. Sci. 2013;18:157-166.

9. Chauhan RP, Nain M, Kant K. Radon diffusion studies through 
some building materials: Effect of grain size. Radiat. Meas. 2008;43:445-448.

10. Dempsey S, Lyons S, Nolan A. High radon areas and lung cancer prevalence: Evidence from Ireland. J. Environ. Radioact. 2018;182:12-19.

11. Shukla A, Parmar P, Saraf M. Radiation, radionuclides and bacteria: An in-perspective review. J. Environ. Radioact. 2017;180:27-35.

12. Ravanat J, Douki T. UV and ionizing radiations induced DNA damage, differences and similarities. Radiat. Phys. Chem. 2016;128:92-102.

13. Bolsunovsky A, Frolova T, Dementyev D, Sinitsyna O. Low doses of gamma-radiation induce SOS response and increase mutation frequency in Escherichia coli and Salmonella typhimurium cells. Ecotoxicol. Environ. Saf. 2016;134:233-238.

14. Rozhko TV, Guseynov OA, Guseynova VE, Bondar AA, Devyatlovskaya AN, Kudryasheva NS. Is bacterial luminescence response to low-dose radiation associated with mutagenicity? J. Environ. Radioact. 2017;177:261-265.

15. Min J, Lee CW, Gu MB. Gamma-radiation dose-rate effects on DNA damage and toxicity in bacterial cells. Radiat. Environ. Biophys. 2003;42:189-192.

16. Calabrese EJ. Converging concepts: Adaptive response, preconditioning, and the Yerkes-Dodson Law are manifestations of hormesis. Ageing Res. Rev. 2008;7:8-20.

17. Selivanova MA, Rozhko TV, Devyatlovskaya AN, Kudryasheva NS. Comparison of chronic low-dose effects of alpha- and beta-emitting radionuclides on marine bacteria. Cent. Eur. J. Biol. 2014;9:951-959.

18. Mosse IB. Genetic effects of ionizing radiation - Some questions with no answers. J. Environ. Radioact. 2012;112:70-75.

19. Kaur M, Kumar A, Mehra R, Mishra R. Study of radon/thoron exhalation rate, soil-gas radon concentration, and assessment of indoor radon/thoron concentration in Siwalik Himalayas of Jammu and Kashmir. Hum. Ecol. Risk Assess. 2018;24: 2275-2287.

20. Abumurad KM, Al-Tamimi M. Emanation power of radon and its concentration in soil and rocks. Radiat. Meas. 2001;34:
423-426.

21. Hosoda M, Shimo M, Sugino M, Furukawa M, Fukushi M. Effect of soil moisture content on radon and thoron exhalation. J. Nucl. Sci. Technol. 2007;44:664-672.

22. Breitner D, Arvela H, Hellmuth KH, Renvall T. Effect of moisture content on emanation at different grain size fractions - A pilot study on granitic esker sand sample. J. Environ. Radioact. 2010;101:1002-1006.

23. Mumtaz S, Streten-Joyce C, Parry DL, McGuinness KA, Lu $\mathrm{P}$, Gibb KS. Fungi outcompete bacteria under increased uranium concentration in culture media. J. Environ. Radioact. 2013;120:39-44.

24. Gorman-Lewis D, Elias PE, Fein JB. Adsorption of aqueous uranyl complexes onto Bacillus subtilis cells. Environ. Sci. Technol. 2005;39:4906-4912.

25. Fowle DA, Fein JB, Aaron M. Experimental study of uranyl adsorption onto Bacillus subtilis. Environ. Sci. Technol. 2000;34:3737-3741.

26. Islam E, Sar P. Diversity, metal resistance and uranium sequestration abilities of bacteria from uranium ore deposit in deep earth stratum. Ecotoxicol. Environ. Saf. 2016;127:12-21.

27. Nedelkova M, Merroun ML, Rossberg A, Hennig C, Selenska-Pobell S. Microbacterium isolates from the vicinity of a radioactive waste depository and their interactions with uranium. FEMS Microbiol. Ecol. 2007;59:694-705.

28. Suzuki Y, Banfield JF. Resistance to, and accumulation of, uranium by bacteria from a uranium-contaminated site. Geomicrobiol. J. 2004;21:113-121.

29. Beyaz R, Kahramanogullari CT, Yildiz C, Darcin ES, Yildiz M. The effect of gamma radiation on seed germination and seedling growth of Lathyrus chrysanthus Boiss. under in vitro conditions. J. Environ. Radioact. 2016;162-163:129-133.

30. Cox MM, Battista JR. Deinococcus radiondurans - The consummate survivor. Nat. Rev. Microbiol. 2005;3:882-892.

31. Baek K, Chung EJ, Choi GG, Kim MK, Lim S, Choi A. Deinococcus koreensis sp. Nov., a gamma radiation-resistant bacterium isolated from river water. Int. J. Syst. Evol. Microbiol. 2018;68:2545-2550. 